\begin{tabular}{|l|l|l|}
\hline \multicolumn{2}{|c|}{ PublisherInfo } \\
\hline \hline PublisherName & $:$ & BioMed Central \\
\hline \hline PublisherLocation & $:$ & London \\
\hline \hline PublisherImprintName & $:$ & BioMed Central \\
\hline \hline
\end{tabular}

\title{
Early inklings about SARS
}

\begin{tabular}{|l|l|l||}
\hline \multicolumn{2}{|c|}{ ArticleInfo } \\
\hline \hline ArticleID & $:$ & 4729 \\
\hline \hline ArticleDOI & $:$ & $10.1186 /$ gb-spotlight-20030325-01 \\
\hline \hline ArticleCitationID & $:$ & spotlight-20030325-01 \\
\hline \hline ArticleSequenceNumber & $:$ & 81 \\
\hline \hline ArticleCategory & $:$ & Research news \\
\hline ArticleFirstPage & $:$ & 1 \\
\hline \hline ArticleLastPage & $:$ & 4 \\
\hline \hline & & RegistrationDate : 2003-3-25 \\
\hline ArticleHistory & $:$ & OnlineDate \\
\hline \hline ArticleCopyright & $:$ & BioMed Central Ltd2003-25 \\
\hline \hline ArticleGrants & $:$ & \\
\hline \hline ArticleContext & $:$ & 130594411 \\
\hline \hline
\end{tabular}




\section{Emma Hitt}

Email: emma@emmasciencewriter.com

On February 11, 2003, the Chinese Ministry of Health first informed the World Health Organization (WHO) that 305 cases of a severe atypical pneumonia had occurred in the Guangdong Province in southern China. But on February 10, the word had already gone out on the ProMED-maillistserv, an unofficial worldwide e-mail network for swift reporting of emerging infectious diseases.

The Guangdong pneumonia outbreak has now been linkedto the cases of Severe Acute Respiratory Syndrome (SARS) that spread from the mainland to Hong Kong, Vietnam and countries around the globe, prompting WHO's first global outbreak alert in a decade. But conjecture about a connection between the two outbreaks began early in ProMED-mail, whose multiple daily updates include official and anecdotal reports, insights about symptoms and epidemiology, suggested avenues of investigation and cautionary commentary by specialist moderators.

"What prompted us to start this listserv was a concern about the ability to put out early warning of infections worldwide," said Stephen Morse, director of Columbia University's Mailman School of Public Health and founding chair of ProMED, the Federation of American Scientists' Program for Monitoring Emerging Diseases.

"We discovered that there was no easy way for people to communicate, and ProMED-mail is able to connect people from around the world in areas that don't necessarily have a healthcare infrastructure," he told The Scientist. "Access to e-mail is the only requirement."

Established in 1994, the ProMED-mail listserv has grown from fewer than 100 subscribers to a current list of some 24,000 subscribers in more than 140 countries.

ProMED-mail is not the only listserv available to infectious disease specialists, said Morse, but it was the first of its kind and continues to be the most extensive listserv, covering animal, plant, and humans infections. In fact, subscribers cannot opt out of receiving certain types of posts because, as the organizers point out on the ProMed-mail Web site, "the next plant or animal epidemic may have direct consequences on the human population."

Their point was illustrated shortly after the first pneumonia reports from Guangdong. In midFebruary, cases of avian flu in a Hong Kong father and son also prompted inquiries and speculation among ProMED-mail participants about a possible connectionto the mystery pneumonia on the mainland because the family had traveled through Guangdong province before falling ill.

Any severe respiratory syndrome outbreak in East Asia provokes intense interest among infectious disease specialists who believe that another 1918-style killer flu pandemic is inevitable, and will most likely emerge in that region.

Last week, the Institute of Medicine (IOM) issued a report warning that the US and the world are unprepared to respond to such an outbreak and called for improved efforts to combat infectious diseases, including improved reporting, which the IOM committee said, "remains inadequate." 
John Ward, with the Centers for Disease Control and Prevention (CDC), oversees the CDC's epidemiologic information exchange program Epi-X, a closed reporting system that links the CDC with about 1400 officials at local health and state departments.

"The difference between Epi-X and ProMED-mail is that for Epi-X, we allow only designated officials from health agencies and we try to link experts together with it," said Ward.

Another difference between the systems is that Epi-X is limited to US state and local health departments; and while the WHO used Epi-X to share early information about the SARS outbreak, reporting of the outbreak was relatively late compared to that of ProMED-mail.

An advantage of ProMED-mail, said Morse, is that anyone can join, making it a very open and informal system, whereas "anything going through official channels has to carry the imprimatur of the government, and that can take time."

Although anyone can subscribe, designated area experts voluntarily moderate ProMED-mail and screen, review, and investigate reports before posting them to the network. Each moderator, said listserv founder Jack Woodall, spends an average of three to six hours a day in this task.

Ruth Berkelman, co-author of the IOM report and professor of epidemiology at Emory University, stressed that increasing the capability to detect the emergence of disease is critical whether for a new disease, the emergence of well-recognized diseases in a new part of the world, or an agent used maliciously, such as anthrax.

ProMED-mail is an example of how infectious disease practitioners and interested persons can informally communicate about infectious diseases, Berkelman said. "There are other similar examples, although ProMED-mail is one of the most well-known and well-subscribed."

Sometimes the observations reported cannot be confirmed, she added, but ProMED-mail may supplement more routine government tracking systems such as direct disease notification by countries to the WHO.

\section{References}

1. ProMED-mail, [http://www.promedmail.org/pls/askus/f?p=2400:1000] 
2. Walgate R: Guangdong doctor linked to SARS outbreak. The Scientist, March 20, 2003., [http://www.the-scientist.com/news/20030320/09/]

3. ProMED, [http://www.fas.org/promed/]

4. Powledge T: Genetic analysis of bird flu. The Scientist, February 27, 2003., [http://www.thescientist.com/news/20030227/04/]

5. Walgate R: Hunt for SARS agent intensifies. The Scientist, March 18, 2003., [http://www.thescientist.com/news/20030318/05/]

6. Institute of Medicine: Microbial Threats to Health: Emergence, Detection, Response. The National Academies Press, March 19, 2003., [http://www4.nationalacademies.org/news.nsf/isbn/ 030908864X?OpenDocument]

7. Epi-X, [http://www.cdc.gov/epix/]

8. Woodhall J: ProMED-mail: Background and Purpose. Emerging Infectious Diseases, June 2001., [http://www.cdc.gov/ncidod/eid/vol7no3_supp/woodall.htm] 